\title{
NOTES ON VELIGERS OF JAPANESE OPISTHOBRANCHS (3)
}

$\operatorname{AUTHOR}(S)$ :

Hamatani, Iwao

\section{CITATION:}

Hamatani, Iwao. NOTES ON VELIGERS OF JAPANESE

OPISTHOBRANCHS (3). PUBLICATIONS OF THE SETO MARINE

BIOLOGICAL LABORATORY 1961, 9(1): 67-79

\section{ISSUE DATE:}

1961-05-30

URL:

http://hdl.handle.net/2433/174661

RIGHT: 


\title{
NOTES ON VELIGERS OF JAPANESE OPISTHOBRANCHS $(3)^{i, 2)}$
}

\author{
IWAO HAMATANI \\ Sennan Senior High School, Sennan City, Osaka Pref.
}

With 10 Text-figures

Succeeding my previous papers on the veligers of seven Japanese opisthobranchs, here is presented the third paper of the same series in which the following three species are treated: they are Philine japonica LISCHKE and Doridium gigliolii (TAPPARONE-CANEFrI) of Philinacea, both collected from the Zostera-zone at Tannowa on the southeastern coast of Osaka Bay, and Goniodoris sugashimae BABA of Okeniidae (=Goniodorididae) caught at Kada situated about $9.5 \mathrm{~km}$. southwest to Tannowa. The observations were made on egg-masses spawned in my private laboratory by animals collected at the above-mentioned localities.

\section{Philine japonica LISCHKE}

(Figs. 1-3)

Descriptions including some figures on this opisthobranch were recently given by following two papers: HAMADA and INO (1957) made clear the feeding and spawning habits and the destribution of this animal in Tokyo Bay and TANAKA (1958) described on the pelagic larva and gave figures of its shell. However, the detailed morphological descriptions and figures of the newly hatched veliger of this species has never been given by any workers. So, the present author is going to give here some biological notes of this animal and the details of morphological observations of the newly hatched veliger.

This species is 25 to $30 \mathrm{~mm}$ in length, light grayish white faintly with a yellowish tint, and can be found commonly in considerable numbers on the muddy sand-zone covered with Zostera marina at Tannowa during the months from February to June. Spawning occurs in the same season, but especially frequently in the period from March to April when the water temperature ranges from $13^{\circ}$ to $16^{\circ} \mathrm{C}$. Thus, only a single spawning season is seen in a year at Tannowa, although two spawning seasons were found in Tokyo Bay, respectively in the

1) Contributions from the Seto Marine Biological Laboratory, No. 362.

2) A part of the studies supported by the financial aid granted from the Ministry of Education.

Publ. Seto Mar. Biol. Lab., IX (1), 1961. (Article 6) 
months from April to June and the period from September to December (Hamada and INO, 1957). The stomach content consists chiefly of a great many shells of Decorifer matusimana (Cephalaspidea, Opisthobranchia) and those of small bivalve mollusks, sometimes even the cannibal habit is observed. HAMADA and INO (1957) state also that this animal feeds on small bivalves and snails.
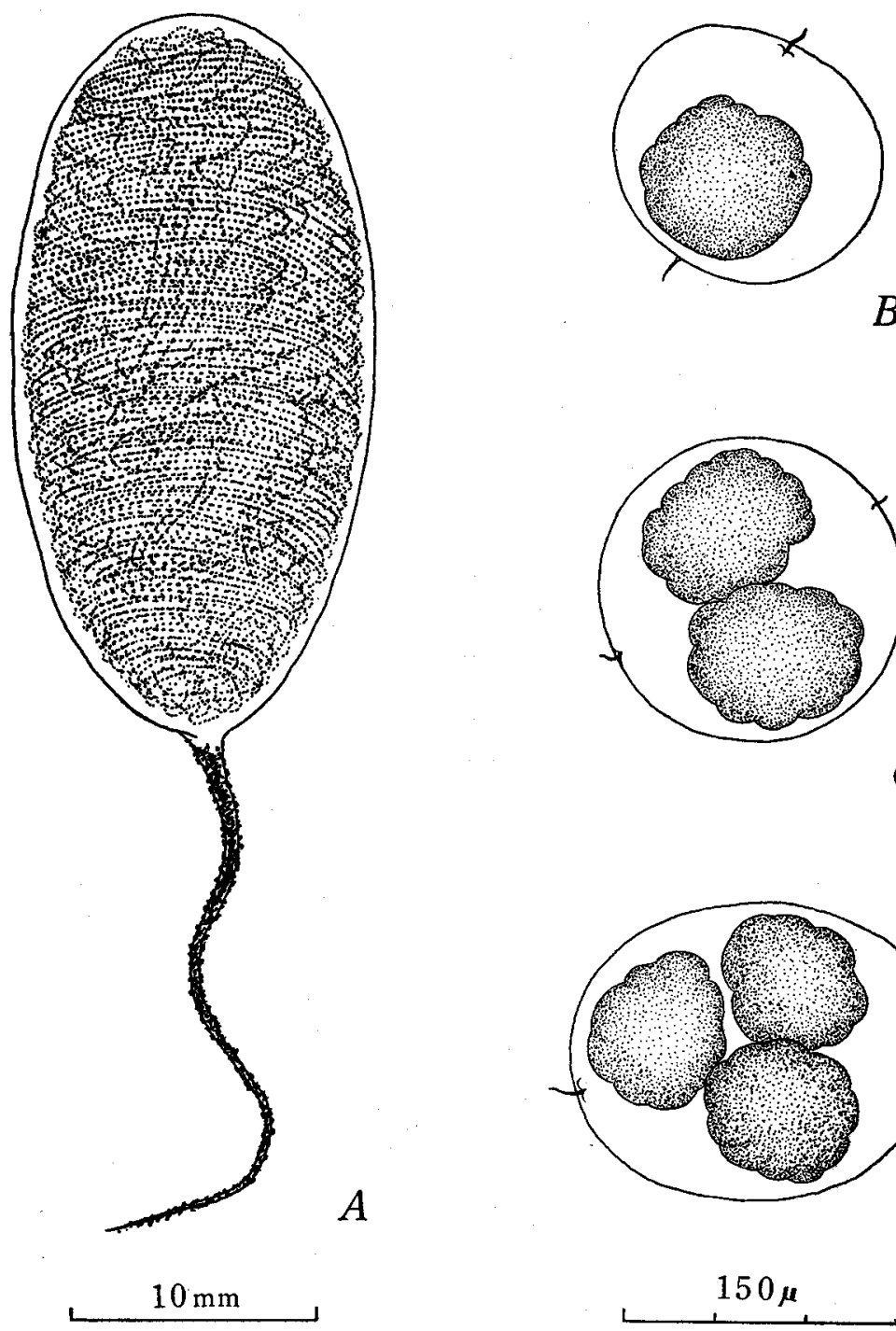

$B$

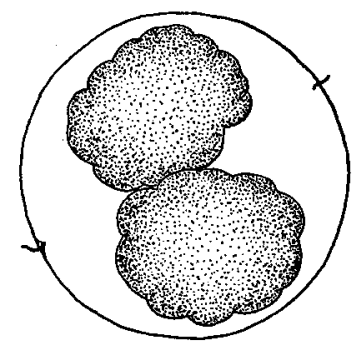

C
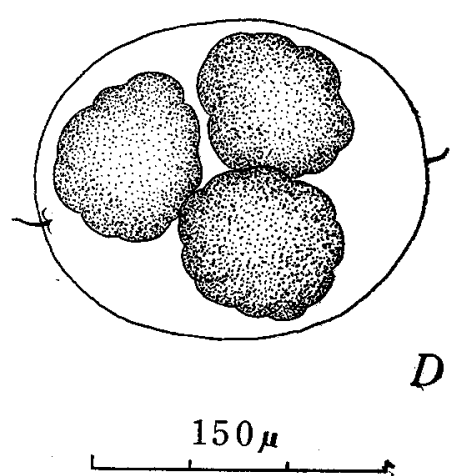

Fig. 1. Philine japonica LIschKe.

A. Egg-mass.

B. Egg-capsule with one ovum.

C. Egg-capsule with two ova.

D. Egg-capsule with three ova. 
The egg-mass (Fig. 1, A) is generally elongate oval in outline and varies from 25 to $60 \mathrm{~mm}$ in length and from 10 to $25 \mathrm{~mm}$ in diameter, with an average $35 \mathrm{~mm}$ in length and $15 \mathrm{~mm}$ in diameter. It is slightly brownish in colour and inserted in muddy sand with the proximal tail-like protuberance. The egg-capsules are provided each of a mucous string at each end and connected one another in a series, and the string of egg-capsules thus formed makes numerous regular

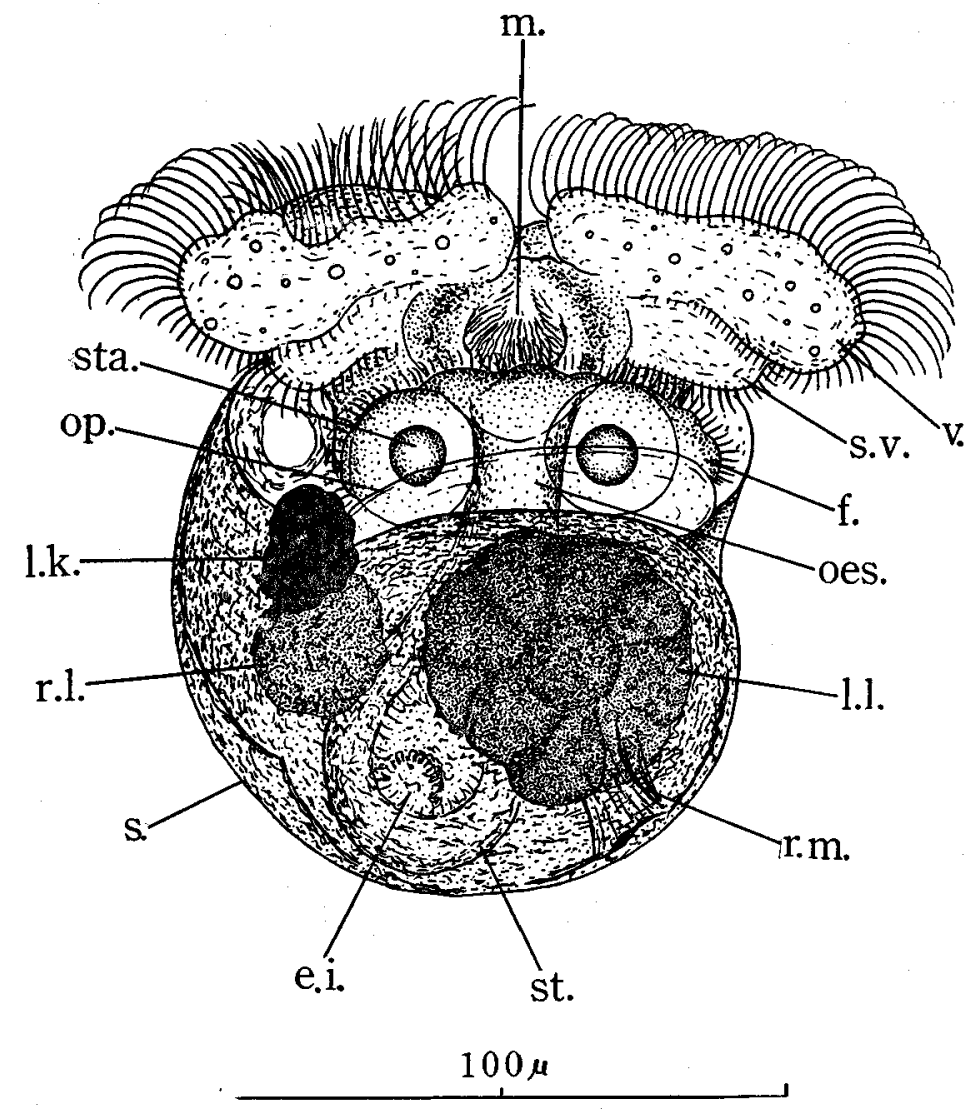

Fig. 2. Philine japonica LrschKE.

Newly hatched veliger, from the ventral side.

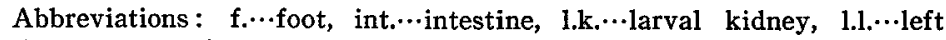
liver, $m \cdots$ mouth, oes. $\cdots$ oesophagus, e.i. $\cdots$ entrance to the intestine, op. $\cdots$

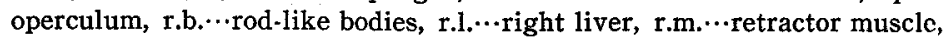

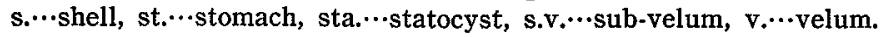

coils within the clear gelatinous envelope. These features are almost the same as those of Philine aperta (Guiart 1901, Tchang 1931, Thorson 1946) and $P$. kinglipini (Tchang 1934). Each capsule contains 1 to 3 ova (Fig. 1, B-D). The diameter of egg-capsules varies from 130 to $200 \mu$ and that of ova ranges from 83 to $86 \mu$. 
Early development: The egg-mass was kept in a glass-vessel at the room temperature of $5^{\circ}-21^{\circ} \mathrm{C}$. Embryos reached the earliest stage of veliger on the tenth day, in this stage they are marked on the right side with the larval kidney slightly pigmented in purplish red. This pigmentation of the larval kidney becomes gradually heavy with development, till it looks jet-black. The hatching out of veligers began on the thirteenth day and continued for three days.

Veligers: Newly hatched veligers (Fig. 2) are nearly roundish in shape and 130 by $150 \mu$ in size on an average. Shell (Fig. 3) is sinistral, roundish ovoid in shape and 110 to $135 \mu$ in long diameter. It is colourless, but furnished densely

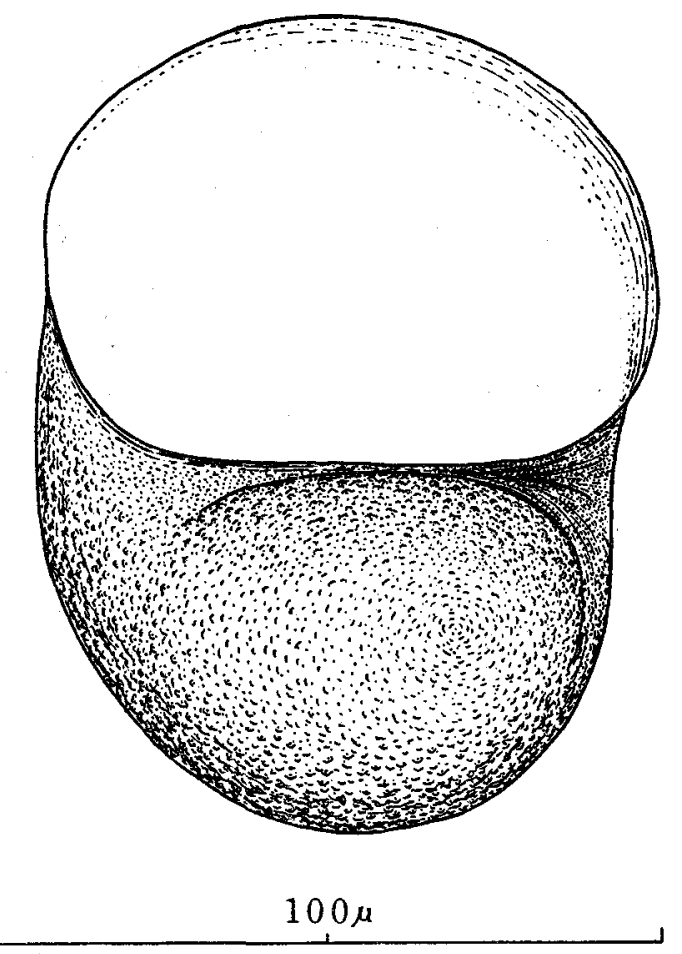

Fig. 3. Philine japonica LischKe.

Larval shell, from the ventral side.

with very fine papillose sculptures. Therefore it is somewhat difficult to observe the visceral organs from the outside of shell. The aperture is very large, occupying more than a half of the whole frontal projection of the shell and with the columellar edge nearly straight. Unfortunately the operculum was not observed by the present author, although TANAKA (1958) mentions it is "paucispiral" and his figure shows a semicircular outline and $2 \frac{1}{2}$ coils. The bilobed velum is unpigmented and contains several refracting granules. The subvelum is present. There are no eyes as in larvae of other Philinids (THORson 1946), although statocysts are well marked. The foot is ciliated with numerous short cilia all 
over the surface and tapers off at the end in a pointed shape. The mouth is rather large and unpigmented. The broad oesophagus leads straight to the stomach. There are some so-called "rod-like bodies" seen in the wall of the right side of stomach (see Fig. 5 B of Doridium gigliolii) just as in the case of Archidoris pseudoargus mentioned by THOMfson (1959). There are two liver-lobes, they are opaque and slightly brownish yellow in colour. The left lobe is much larger than the right; both lobes are devoid of any refracting granules in the tissue. This latter feature differs distinctly from that of Doridium gigliolii belonging to the same family and described next. Sometimes black pigments are seen on the surface of the left liver lobe. The intestine starts from the dorso-posterior part of stomach and probably leads straight to the anus, so it can not be seen from the ventral side. A large jet-black larval kidney is found on the right side of the body as already described by HAMADA and Ino (1957) and TANAKA (1958); this is a well known feature in Philinids as mentioned by THORson (1946).

\section{Doridium gigliolii (TAPPARONE-CANEFRI)}

(Figs. 4-6)

This species appears also in considerable numbers and spawns in the muddy sand-zone at Tannowa during the same season as that mentioned in the case of the preceding Philine japonica. Sometimes many empty shells of Decorifer. matusimana were found in feces, probably the feeding habit of this species is quite the same as that of $P$. japonica. The structure of the egg-mass of this species is similar to the general type found in the genus Philine. Unlike that of P. japonica, however, the egg-mass (Fig. 4, A) of this species is very slender and milky white in colour. An egg-filament is enclosed within the clear gelatinous envelope in spiral coils, although they are not so regular as in $P$. japonica. The egg-mass is also anchored to the bottom by inserting a tail-like protuberance issued from the proximal end into the muddy sand. The shape of the egg-mass and the somewhat irregular arrangement of egg-filament are very similar to those of Doridium carnosum and D. depictum, var. minor described by TCHANG (1931 and 1934). The egg-mass varies from 20 to $53 \mathrm{~mm}$ in length and 6 to $18 \mathrm{~mm}$ in diameter, with an average $30 \mathrm{~mm}$ in length and $10 \mathrm{~mm}$ in diameter. The number of ova within the egg-capsule varies according to mass, from 1 to 2 (rarely 3 ) in some masses or 3 to 4 (rarely 1 or 5 ) in others (Fig. 4, B-D). Tchang (1931) states "La nombre d'oeufs que contient une coque est de 3 à 4 ou de 7 à 11, suivant la ponte" as to D. carnosum. An animal collected at Tannowa on March 2, 1960 and brought to the laboratory was found spawning in the afternoon of March 10 when the water temperature was $19^{\circ} \mathrm{C}$. The spawn was $20 \mathrm{~mm}$ in length and $7 \mathrm{~mm}$ in diameter. In this egg-mass, only a single ovum was contained in each egg-capsule. The diameter of these egg-capsules was $150 \mu$ on an average and that of ova was about $85 \mu$. 
Early development: The above-mentioned egg-mass was kept at the room temperature of $10^{\circ}-22^{\circ} \mathrm{C}$. It was on the third day of the development that embryos reached the gastrula stage; at this stage the embryos are triangular in shape. The rotatory motion of embryos of the trochophore stage in the capsule commenced on the forth day, and the embryos passed into the earliest stage of
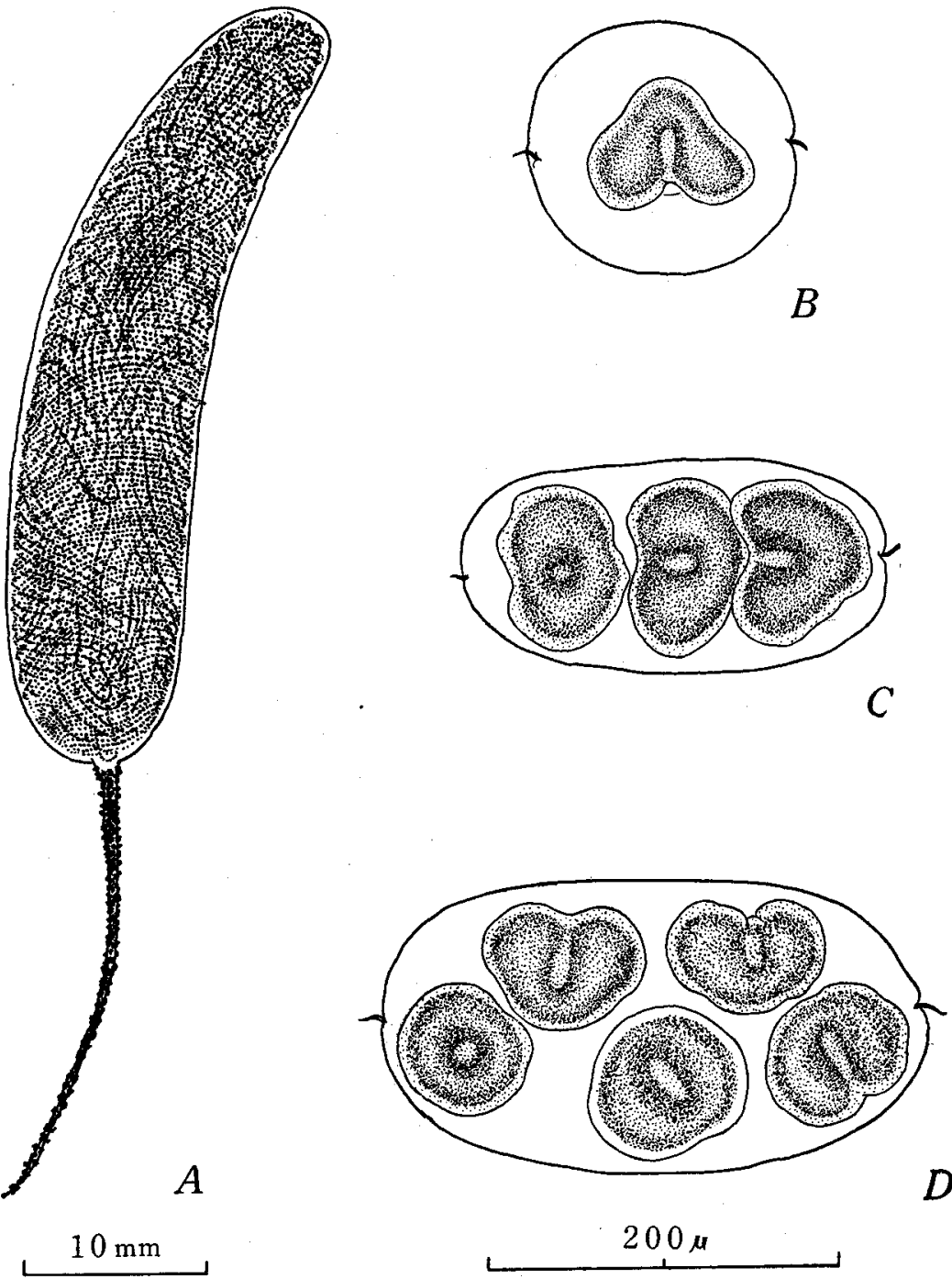

Fig. 4. Doridium gigliolii (TAPPARONE-CANEFRI).

A. Egg-mass.

B. Egg-copsule with one ovum.

C. Egg-capsule with three ova.

D. Egg-capsule with five ova. 

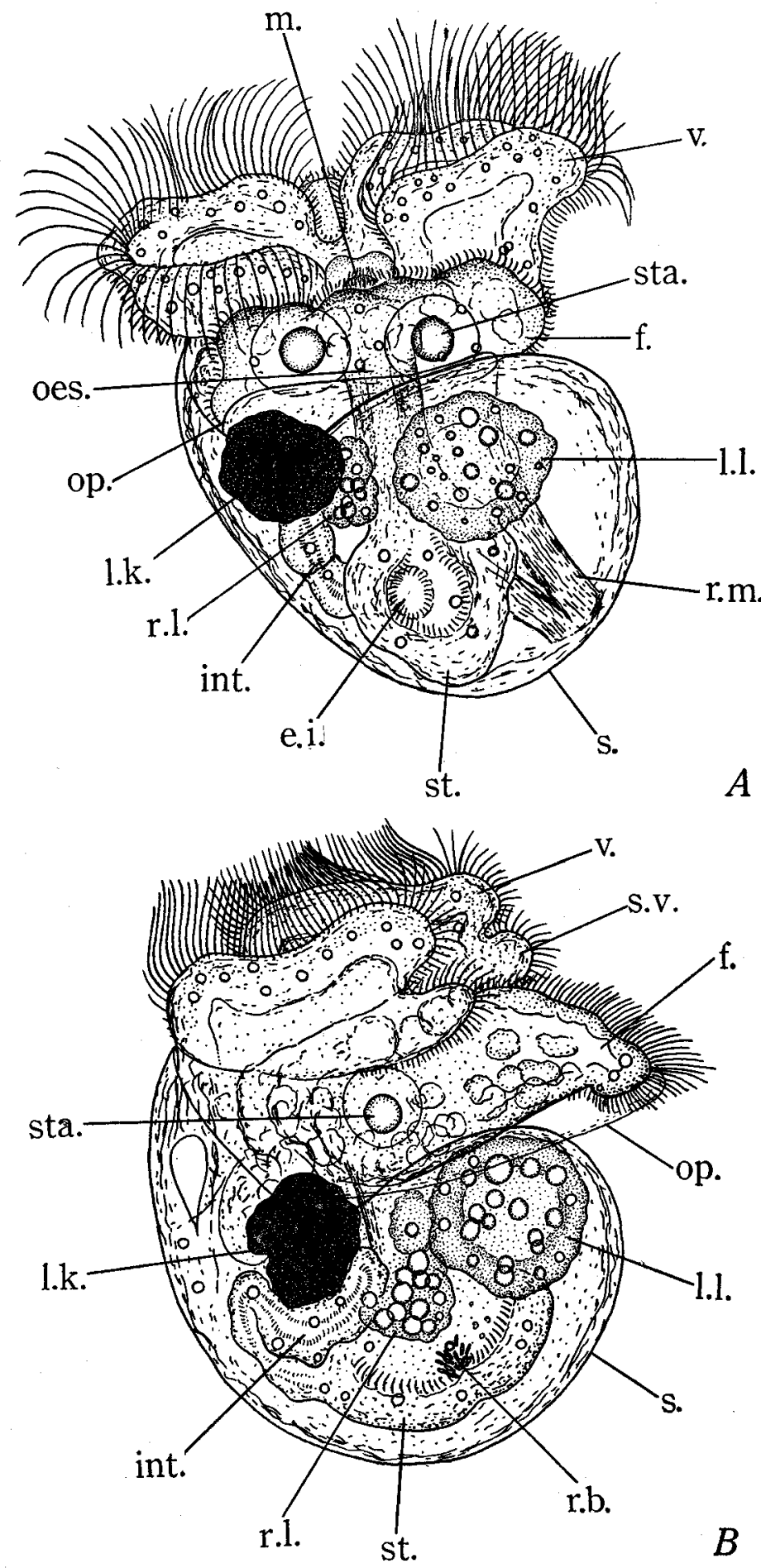

$100 \mu$

Fig. 5. Doridium gigliolii (TAPPARONE-CANEFRI).

A. Newly hatched veliger, from the ventral side.

B. The same, from the right side.

(For abbreviations see Fig. 2.) 
veliger on the sixth day. On the tenth day the embryos attained the nearly completed veliger stage and on the next day the hatching out of larvae from the egg-mass was observed and it continued all the twelfth day.

Veligers: The structure of the newly hatched veligers (Fig. 5, A-B) are nearly the same as those of the preceding species $P$. japonica. The body is about $135 \mu$ in length on an average. The larva is quite colourless exclusive of the liver lobes and a large jet-black larval kidney on the right side of the body. This pigmentation of the larval kidney agrees with that commonly found in forms of the genus Philine. The shell of the newly hatched veliger (Fig. 6) is sinistral,

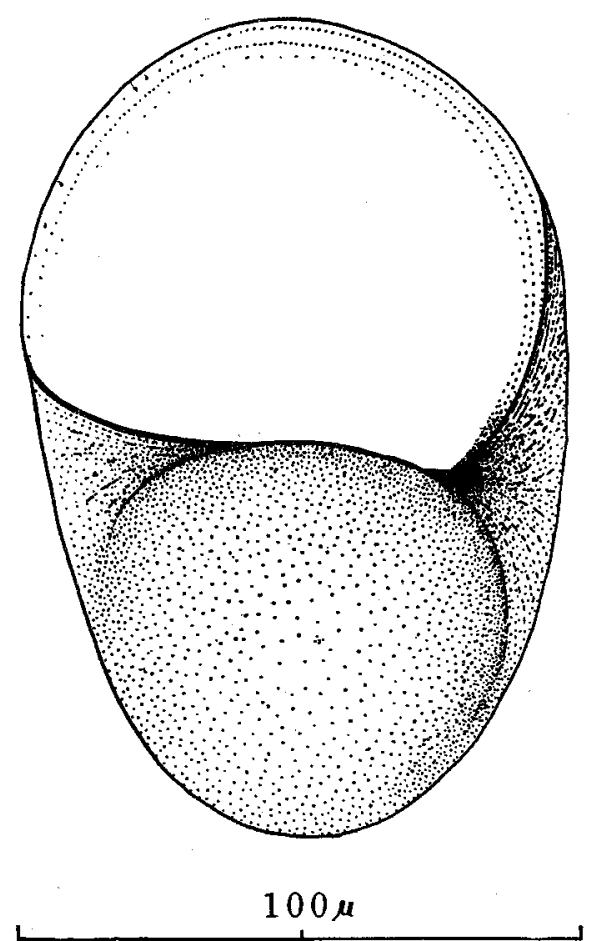

Fig. 6. Doridium gigliolii (TAPPARONE-CANEFRI). Larval shell, from the ventral side.

transparent, colourless and sculptured with very minute dots densely set. The shell ranges $1: \ldots 110$ to $200 \mu$ in long diameter and with an average of $140 \mu$, and it is not so rowded as in P. japonica. The aperture is large, 85 to $102 \mu$ in the diameter and with an average of $94 \mu$, it occupies about half of the whole frontal projection of the shell. The operculum is circular and has a spiral line coiling about 13/4 times. Subvelum is present; the velum and of ten the subvelum, too, have several refracting granules in the tissue. Statocysts are present, but the eyes are not formed in this species, either. The foot is ciliated and the end tapers off in a triangular shape just as in the preceding species; this feature 
seems to be a characteristic common to these species. The mouth is ciliated and unpigmented, and the oesophagus is rather stout. The stomach contains some refracting granules in the wall, but not pigmented. So-called "rod-like bodies" are seen distinctry on the right side of stomach; but the area containing these bodies is rather smaller than in $P$. japonica. Two liver lobes are present, the left lobe is larger, as usual, than the right which is comparatively smaller than that of P. japonica. Both lobes are translucent, yellowish brown in colour, and contain very large refracting granules in their walls; this aspect is a character unique to the veliger of this species differentiating it distinctly from that of the preceding species $P$. japonica. The intestine is long and assumes a S-shaped course when it is seen from the right side. It has some refracting granules in the wall.

\section{Goniodoris sugashimae BABA}

(Figs. 7-10)

A single specimen of this species was collected from the under surface of a stone near the low water mark at Kada on April 26, 1960, and an egg-mass was found near by. This specimen laid an egg-mass on the bottom of a glass-vessel when it was brought in the laboratory on the same day. This egg-mass (Fig. 7, A) was quite the same as that found in the natural environment. It resembles
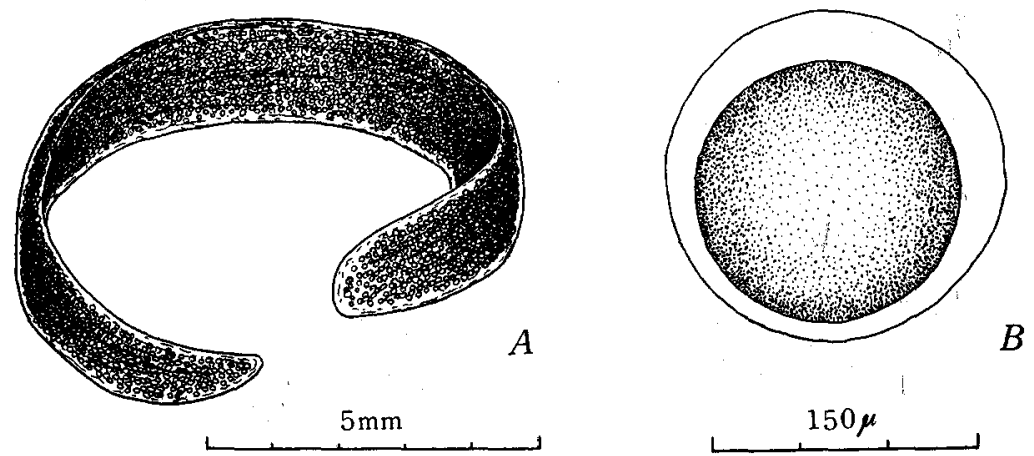

Fig. 7. Goniodoris sugashimae BABA.

A. Egg-mass.

B. Ovum in the capsule.

somewhat that of Goniodoris castanea (BABA, Hamatani and Hrsai, 1956): it is milky white in colour and consists of a $20 \mathrm{~mm}$ long ribbon which is $3 \mathrm{~mm}$ broad and attached to the substratum by an edge along its whole length and forms an incomplete circle with a $7 \mathrm{~mm}$ diameter. A single ovum, $119 \mu$ in diameter in an examined sample, is contained in each elliptical egg-capsule (Fig. 7, B) whose diameters are respectively 145 and $155 \mu$, for example. 

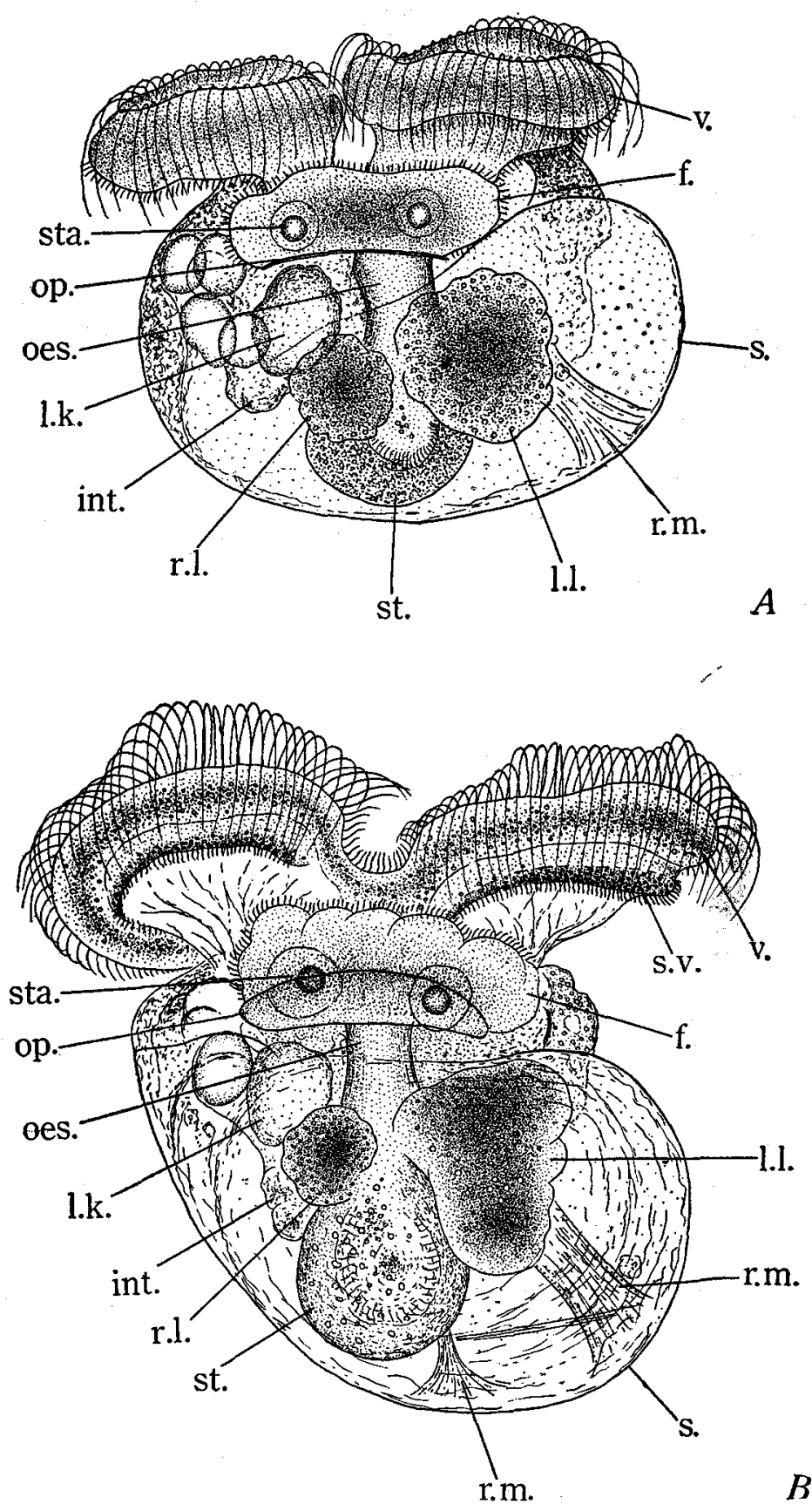

$200 \mu$

Fig. 8. Goniodoris sugashimae BABA.

A. Intra-capsular veliger 6 days old, from the ventral side.

B. Intra-capsular veliger 7 days old, from the ventral side.

(For abbreviations see Fig. 2.) 

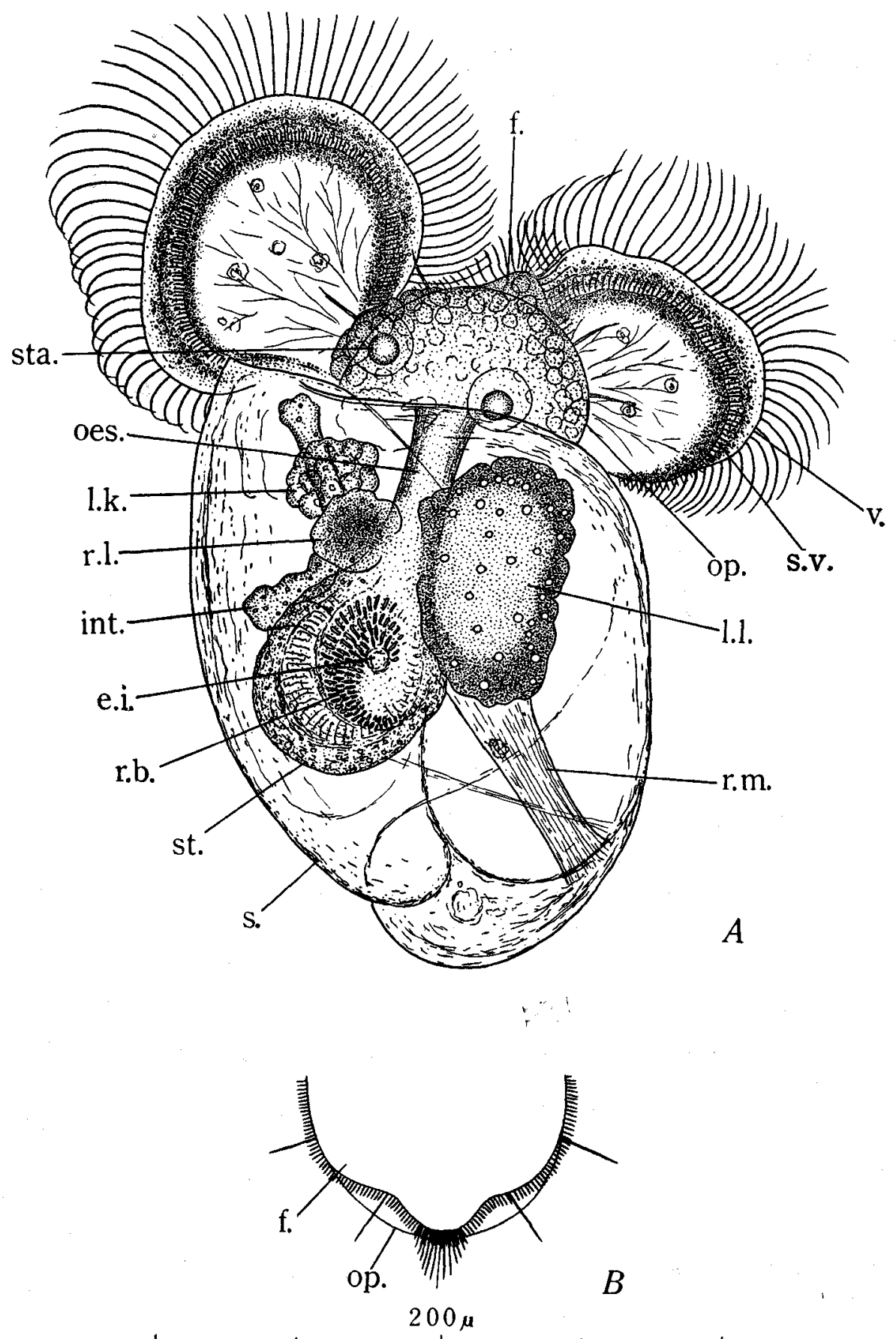

Fig. 9. Goniodoris sugashimae BABA.

A. Newly hatched veliger, from the ventral side.

B. Foot and operculum, showing the sensory cilia. (For abbreviations see Fig. 2.) 
Early development: On the fourth day all the embryos had already developed to a veliger-like shape. On the sixth day, the intra-capsular veligers (Fig. 8, A) attained $170 \mu$ antero-posteriorly, the shell assumed an antero-posteriorly compressed form and with sculptures consisting of very minute dots, and the formation of orgaus was nearly completed. On the seventh day the veligers (Fig. 8, B) had grown to be about $230 \mu$ antero-posteriorly and distinctly was provided with the subvelum. On the next day the first hatching out was observed and this

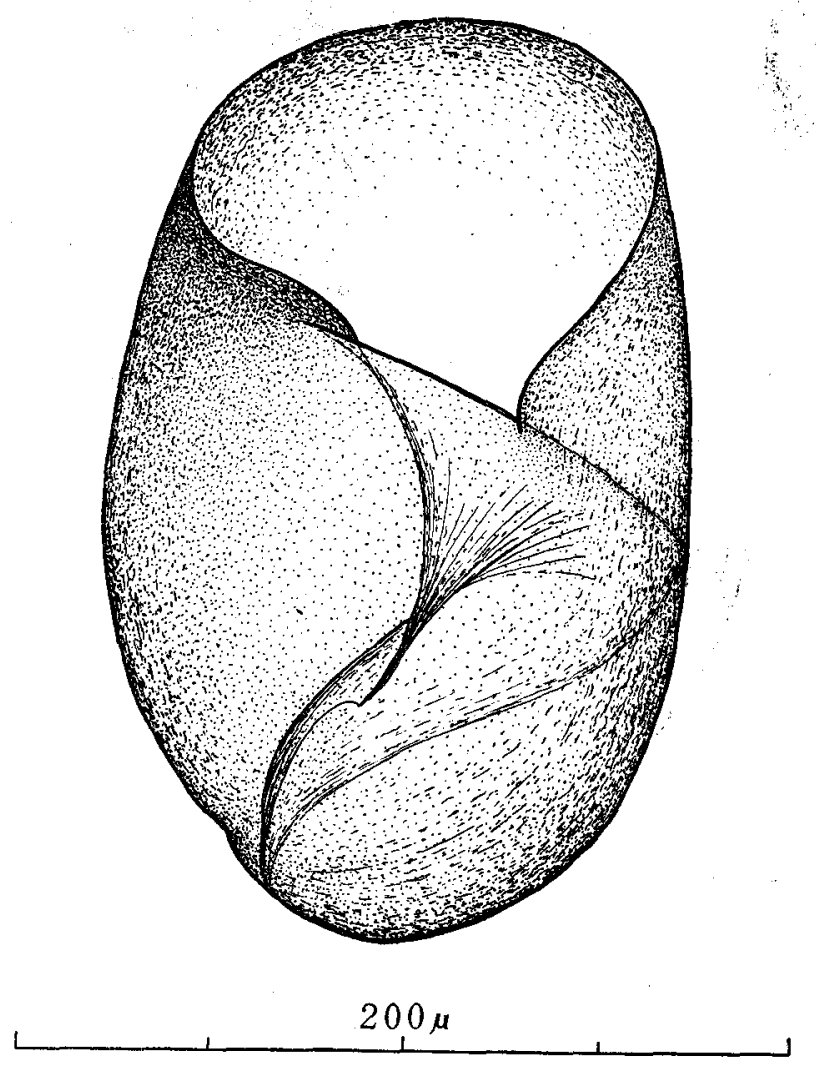

Fig. 10. Goniodoris sugashimae BABA. Larval shell, from the ventral side.

continued for two days. During the observations the room temperature fluctuated from $15^{\circ}$ to $25^{\circ} \mathrm{C}$.

Veligers: The newly hatched veligers (Fig. 9, A) is very peculiar in form. The whole body is somewhat elongate, rather large, $300 \mu$ in antero-posterior diameter for instance, transparent and quite colourless. The structure of shell (Fig. 10) is quite unique, it is well developed, elongate ovoid in shape, $230 \mu$ in long diameter on an average, and with a sinistro-spiral columella. The operculum is circular and with a spiral line. The subvelum is present, both the velum and 
subvelum are devoid of any refracting granules. The statocysts are distinct and statolith looks somewhat lighter than in other species; eyes absent. The foot is covered with numerous short cilia all over the surface. Some long sensory cilia (Fig. 9, B) are issued from the periphery of the foot, four of which are arranged two on each side and other several ones at the tip. The foot contains many large cells in the tissue. The tip is tapering, but it does not protrude beyond the operculum edge. The stomach is characterized in having a broad zone of "rod-like bodies" which can be seen very distinctly from the ventral side. There are two liver lobes: the right lobe is smaller than the left, connected with the right side of the entrance to the stomach and contains several very minute refracting granules, while the left one is very large, connected with the left side of the entrance to the stomach and contains some refracting granules larger than those of the right lobe. The intestine is slender and the larval kidney is colourless.

\section{LITERATURE CITED}

BaBA, K., Hamatani, I. and Hisai, K. 1956. Observations on the spawning habits of some of the Japanese Opisthobranchia (II). Publ. Seto Mar. Biol. Lab., Vol. 5, No. 2.

GutarT, J. 1901. Contribution a l'étude des Gastêropodes Opisthobranches et en particulier des Céphalaspides. Mém. Soc. Zool. France, tom. 14.

Hamada, S. and INO, T. 1957. Ecological studies on a predator for commercial clams, Philine japonica Lischke. Bull. Tokai Reg. Fish. Res. Lab., No. 16.

TANAKA, Y. 1958. Studies on molluscan larvae (I). Venus, Vol. 20, No. 2.

TCHANG, S. 1931. Contribution à.l'étude des Mollusques Opisthobranches de la côte provençale. Thèse, Lyon.

Tchang, S. 1934. Contribution a l'étude des Opisthobranches de la côte de Tsingtao. Contrib. Inst. Zool. Nat. Acad. Peiping, Vol. 2, No. 2.

Thompson, T. E. 1959. Feeding in nudibranch larvae. J. Mar. Biol. Ass. U. K., Vol. 38.

THORsoN, G. 1946. Reproduction and larval development of Danish marine bottom invertebrates. Medd. Kommiss. Danmarks Fisk. Havunders., Series Plankton, Vol. 4, No. 1. 